\title{
Accounting
}

\section{Determinants of corporate cash holdings: Evidence from the Moroccan market}

\author{
Boubker Mouline $^{\mathrm{a}^{*}}$ and Hicham Sadok ${ }^{\mathrm{a}}$
}

${ }^{a}$ Mohamed V University in Rabat, Morocco

\section{H R O N I C L E}

Article history:

Received: January 12, 2021

Received in revised format: April 82021

Accepted: April 17, 2021

Available online:

April 17, 2021

Keywords:

Cash holdings

Morocco

Firm specific characteristics

Capital structure theories

Agency theory

\begin{abstract}
A B S T R A C T
Determining cash holdings is amongst the most important financial decisions made by heads of corporations. This decision relies on theoretical convictions and views as well as firm specific characteristics. This article analyzes the determinants of cash management in Moroccan corporations. By mobilizing all the theories of optimal financial structure, our research attempts to focus on the field of knowledge in the financial management of cash surpluses. No analysis has been carried out concerning cash and cash equivalents in Moroccan firms. These results could, therefore, contextualize the existing knowledge in this research theme and better understand the behavior of companies and their main trends in terms of cash flow, as well as the objectives and motivations of managers. The sample studied consists of 42 Moroccan companies, which are all publicly traded on the Casablanca Stock Exchange over 13 years (2007-2019). This research uses an empirical econometric study based on a positivist approach with a hypothetical-deductive method. We use panel regression analysis and perform all the necessary tests to determine the exact nature of this dataset. Our results show some evidence that a strong positive correlation exists between liquidity level and cash-flow as well as family shareholding. It is also found that the cash holdings of these companies are significantly negatively affected by how large or small the firm is, working capital requirement, debt leverage, as well as growth opportunity of the firm.
\end{abstract}

(C) 2021 by the authors; licensee Growing Science, Canada

\section{Introduction}

Since the start of this millennium, liquidity has been more than ever at the heart of corporate policies that hold cash for various reasons. Researchers have paid considerable attention to this fact, which is contrary to theoretical predictions as well as to the proliferation of alternative investment instruments and derivatives to manage this excess optimally. The financial literature has tried to understand the determinants as well as the different motivations for which companies prefer to hold this cash. The liquidity ratio of listed European companies increased on average from 8\% to $17 \%$ of total assets between 1980 and 2015 (Monteiro, Silva, Silva 2018). During the same period of time, cash positions of US companies grew even more significantly, reaching a record level in 2017 with more than USD 1.99 trillion held by US non-financial companies (Moody's 2018). However, classical financial theory teaches us that companies should aim for zero cash flow. As the tools used to manage cash positions become increasingly sophisticated, one might have expected a move towards this theoretical optimum, which implies a decrease in the average cash holdings. However, in reality, the opposite has happened, as cash levels are high and have been

* Corresponding author. Tel: +212-661-243-814

E-mail address: boubker.mouline@um5s.net.ma (B. Mouline) 
growing continuously over the last 35 years. Numerous international studies confirm this observation, for example, the average cash ratio was $23.2 \%$ for American companies in 2016, compared to $10.5 \%$ in 1980 (Bates, Kahle, \& Stulz, 2009), 12.33\% on average in Australia over the period 1990-2015 (La Cava \& Windsor, 2016), and 12\% in India over the period 2005-2015 (Arora, 2019). So, what are the reasons why companies hold cash?

The literature offers several points of view in an attempt to understand the level of liquidity held by companies. These points are understood in the context of compromise theory (Opler et al., 1999), agency theory (Jensen, 1986) and hierarchical order theory (Myers \& Majluf, 1984). In this article, we will analyze the cash flow of 42 Moroccan firms listed on the Casablanca Stock Exchange over a period of 13 years (2007-2019) in the context and in light of these three theories. It is useful to examine this issue in this context, given the lack of studies conducted there, unlike in developed countries. To date, and to our knowledge, no studies have been conducted on the Moroccan market.

The main goal of this article is to pinpoint the significant factors impacting cash holdings of Moroccan companies. This paper contributes to existing literature in the context of the Moroccan case, particularly that of Moroccan non-financial firms publicly traded on the Casablanca Stock Exchange between 2007 and 2019. We use three explanatory theories as a basis to study the determinants of their behavior: compromise, agency, and hierarchical order theory.

This article is structured in the following order: We first briefly review the literature dealing with the optimal capital structure. This review highlights the determinants of cash holdings and identifies the critical variables influencing the company's cash holding decision. Next, we examine the methodology and sampling. We then present and discuss the results. Finally, we summarize the main findings in our conclusion.

\section{The optimal holding level of cash: a literature review}

Multiple theories have been modeled, discussed, and criticized on the topic of cash targets and cash holdings levels in corporations. Arbitration theory states that companies seeking an optimal financial structure must arbitrate amongst the advantages and marginal drawbacks of holding cash, and therefore be incentivized to accumulate liquidity at the level where their marginal cost is equivalent to their marginal profit. Beckhart and Keynes (1936) provide a summary of the main benefits of holding cash: the transaction and precautionary motive. According to the transaction motive, maintaining sufficient levels of cash allows the firm to cut costs associated with accessing capital markets, selling assets, or decreasing dividends. Thus, firms with higher external financing costs, and are therefore more financially constrained, are expected to have a higher level of cash holdings (Kim, Mauer, \& Sherman, 1998). The precautionary motive is associated with lost investment and growth opportunities. Companies dealing with financial constraints may face two situations: either the lack of financing or the disproportionately high cost of that financing when it is available. In these cases, companies must give up their high value-added investment projects (Myers \& Majluf, 1984; Myers, 1984). By having a sufficient level of cash-flow, firms are able to capitalize on every investment opportunity that comes their way and thus avoid the high opportunity cost that would arise from having to abandon these projects. This explains why it is in the interest of these companies to accumulate cash, which can represent a strong safety buffer (Levasseur, 1979). However, liquid assets produce a small return and are considered disadvantaged from a tax perspective (Opler et al., 1999), so the existence of treasury reduces the firm's profitability and could be regarded as financially damaging to the firm. The holding of cash is also considered to be the primary source of shareholder and management conflict of interest and therefore of agency cost (Jensen, 1986; Opler et al.,1999). The costs associated with the principle-agent problem between owners and directors, the tax disadvantage, and the low profitability of cash form the overall costs of holding cash. We can therefore expect our study to reveal that small businesses maintain a higher level of cash compared to large ones as a result of higher compartmental external financing costs. Companies that pay dividends and those with high working capital requirements should have low asset levels, since they always have the option of reducing, deferring, or cancelling dividends and converting receivables and inventory into liquid assets quickly and cheaply (Opler et al.,1999).

As opposed to arbitration theory, which weighs the advantages and disadvantages of the possession of liquidity in order to find the desired treasury level, agency theory puts forward the impact of the managerial discretionary amount of cash held by the firm. Through a pursuit of their own interests, managers may hold more cash than necessary in order to optimize the financial value of the company, and therefore be able to fund investments with negative NPV (Net present value) or low rates of return which capital markets are not willing to finance. Accumulating a large amount of cash would then enable management to reach their own goals at the cost of shareholders' interests, and simultaneously avoid being monitored by the capital market (Jensen \& Meckling, 1976; Harford et al., 2008; Couderc, 2006). The corporate governance literature has shown that management control is an essential means of reducing agency conflict between shareholders and management and encourages them to act in the shareholders' interest. However, in the case of a minority shareholder, the losses associated with monitoring are greater than potential gains, so there is no incentive for the shareholder to effectively monitor management. While for a major shareholder, the benefits of monitoring the directors outweigh the costs, providing incentive for the shareholder to effectively supervise the 
directors. Therefore, the presence of concentrated ownership limits the discretionary behaviour of managers and limits agency conflict between management and minority sharers (Shleiferr \& Vishny, 1986). This leads us to predict a negative link between the percentage of control of the top three shareholders and liquidity levels. From the same perspective, the role of the major shareholders in the control of executives would depend on the identity of these shareholders. In fact, excessive participation in the direction of the firm could lead to a different case of agency conflict, specifically between the majority and minority shareholders. This situation is particularly common in family-controlled firms (Gomes \& Novaes, 2005), allowing us to predict a positive effect of family shareholding on the level of liquid assets. Furthermore, it is important to highlight how the absence of sufficient growth opportunities increases the importance of monitoring the management's behaviour. The absence of investment opportunities would give managers more opportunity to accumulate a maximum of cash, and to invest it in lowprofit projects which would favor their rooting within the company (Ferreira \& Vilela, 2004; Yogesh \& Vigneswara, 2017).

A different view of treasury is derived from the pecking order theory explanation which states that neither an optimal level of liability nor an optimal liquidity level exists. The treasury would only be the outcome of other financing decisions (Myers \& Majluf, 1984). This theory explains that firms avoid issuing new equities to fund their investment plans as a result of information asymmetries. Therefore, in order to finance its investments, a firm primarily uses internal funding, then debt financing when possible, and finally, issued shares. When existing investments generate high amounts of liquidity, the firm will use these investments to support other profitable projects, then pay down debt, distribute dividends to shareholders, and finally gradually save cash (Opler et al., 1999). This leads us to predict in our work a negative relationship between the level of indebtedness and liquidity, and a positive effect of cash flow on the liquidity level of Moroccan firms.

\section{Determinants of Cash Holdings}

Existing literature implies explanatory variables for firms' behaviour when holding cash. The determinants selected from the theoretical and empirical literature are justified in their expected impact on the amount of cash holdings. These determinants affect transaction costs, agency costs, and informational asymmetry. The main determinants of cash levels can be summarized below.

\subsection{Debt}

Under the pecking order theory, a firm with high investment requirements would, to the furthest extent, resort to debt financing if it cannot finance everything with its internal funds, and its debt level will therefore increase while its cash flow level will fall. In contrast, the firm's investment needs are below its reserved profits, and therefore will repay its financial liabilities and collect cash. This implies a negative relationship between leverage and liquidity. Empirical studies have notably revealed a significant negative correlation between the holding of liquid assets and the level of debt (Guney et al., 2007; Ozkan \& Ozkan 2004). The debt of equity ratio is measured as the ratio of debt (long and short-term) to total assets. And from what has been advanced we can make the following assumption H.1 "Corporate indebtedness has a negative impact on the level of liquid asset holdings".

\subsection{Size}

Trade-off theory explains that transaction costs are subject to significant economies of scale when the firm is large, as large firms issue external financing and are therefore able to spread the fixed-cost element of the external financing issue in the context of a large fund. (Smith \& Warner, 1979). Size would also influence the total cost of external financing, since the larger the firm, the greater its bargaining power with bankers (Diamond, 1989). Moreover, small companies are not as diversified and are therefore more likely to fail (Titman \& Wessels, 1988). As a result, small companies are more inclined to collect liquidity (Baumol, 1952; Miller \& Orr, 1966). Empirical studies also show that small entities have a disproportionate level of liquidity compared to their level of activity (Bigelli \& Sanchez-Vidal 2012; Graham \& Leavy, 2018). Firm size is defined as the natural logarithm of total assets. And from what has been advanced we can make the following assumption H.2 "Firm size has a negative impact on the level of liquid asset holdings".

\subsection{Working Capital}

Firms use assets that constitute their working capital requirement in situations of liquidity shortages given the rapid convertibility of receivables and inventory into cash. This implies that these assets are a replacement for cash. Consequently, the correlation between WCR (Working Capital Requirement) and liquid assets would be negative. Numerous investigations show a negative relationship between cash holdings and cash substitutes (Guney et al., 2003; García \& Martínez, 2008; Bigelli et al., 2012). Working capital is approached as the difference between current assets, cash equivalents and current liabilities, divided by total net assets. The working capital ratio is defined as the ratio of working capital to net assets. And from that we can make the following assumption H.3 "Working capital has a positive impact on the level of liquid asset holdings". 
Companies prefer internal sources of financing over outside sources in the presence of information asymmetry (Myers \& Majluf, 1984). Pecking order theory therefore explains that when a company's activities generate high levels of cash flow, it will then fund other profitable projects, subsequently repay debts, distribute dividends or buy back shares, and ultimately accumulate cash (Opler et al., 1999; Ozkan \& Ozkan, 2004). Therefore, the relationship between the level of cash and cash flow would be positive. Empirical evidence shows a positive impact of cash flow on liquidity (Opler et al., 1999; Kalcheva \& Lins, 2004; Graham \& Leavy, 2018). Cash flow is measured by the sum of net operating income and depreciation, which is related to net assets. Therefore, we can advance the following hypothesis H.4 "Cash flow has a positive impact on the level of liquid asset holdings".

\subsection{Dividend}

Firms that pay dividends have less difficulty raising funds since they always have the option of reducing, deferring, or cancelling their dividends (Ferreira \& Vilela, 2004; Opler et al., 1999; Drobetz \& Grüninger, 2007). Dividend reductions are presumed to be linked with low costs and, as a result, firms that pay dividends are not as likely to accumulate cash compared to companies that are not paying them. Therefore, they are not required to carry vast quantities of cash and the relationship between paying dividends and holding cash would be negative. This finding is consistent with several empirical studies, including Bates et al. (2009), and Al-Najjar et al. (2011). The dividend variable is the total dividends distributed during the financial year on total assets. Thus, we can make the following assumption H.5 "Dividend distribution has a negative impact on the level of holdings of liquid assets".

\subsection{Growth Opportunities}

According to agency theory, companies with limited growth opportunities are more exposed to discretionary management risk, since in the face of insufficient growth and openings for investment directors are inclined to accumulate the most liquidity in order to benefit from their discretionary power (Opler et al., 1999), and to then reinvest them in unprofitable projects related to their career and experience, fostering their entrenchment (Ferreira \& Vilela, 2004; Afza \& Adnan, 2007). Several empirical studies show a significantly negative relationship between growth opportunities and cash holdings (Afza \& Adnan, 2007; Baklouti \& Bouri, 2015; Yogesh \& Vigneswara, 2017; Maheshwari \& Rao, 2017). Growth opportunities are represented by Tobin's Q ratio calculated by dividing the market value of equity (Market Capitalization) plus the amount of net financial debt over the net book value of the firm's assets (Book Value). Since net book assets do not consider the presence of growth opportunities, Tobin's $\mathrm{Q}$ will be high for companies with growth opportunities. And from that point we can make the assumption H6 "Growth opportunities are negatively correlated with cash holdings".

\subsection{Ownership Concentration}

The literature discusses how the presence of multiple block holders is widespread (Laeven \& Levine 2008; De Cesari, 2012; Younas, Klein, \& Zwergel, 2017). These authors show that the actions of several majority shareholders play a positive role in the protection of minority shareholders. They have the power to make executive decisions, particularly in regard to dividend distribution. With multiple majority shareholders, the abusive holding of liquidity by managers is much more complicated, which leads several authors to associate the ownership concentration in a company to more effective control by managers (Shleiferr \& Vishny, 1986). Moreover, when shareholding is highly dispersed, the minority shareholders' power over managers is weak. These shareholders will not be able to push them into distributing the cash they have accumulated in the form of dividends or share repurchases, so the level of cash would be high. The shareholding concentration variable is evaluated by the percentage of capital owned by the three main shareholders. Therefore, we are justified in making the following hypothesis H.7 "Concentration of shareholding has a negative impact on the level of liquid asset holdings".

\subsection{Family Shareholding}

According to agency theory, the identity of the controlling shareholder can significantly influence the company's overall financial performance. The role that the significant shareholder can play in controlling management depends heavily on the identity of that shareholder. In fact, excessive presence in the direction of the firm could lead to different forms of agency conflict, this time between majority and minority shareholders. This situation is especially common in family-controlled firms (Gomes \& Novaes, 2005). Furthermore, family-owned companies could pursue objectives beyond economic ones, such as preserving the harmony and social status of the family (Chrisman et al., 2012). Thus, agency costs between majority family shareholders and minority shareholders are significant and therefore lead to high amounts of cash flow. The correlation between family shareholding and cash holdings would be positive. This observation is in line with numerous studies including Anderson and Hamadi (2009), Kuan et al., (2011). Family shareholding is measured by assigning a value of 1 when a family holds more than $20 \%$ of the capital. The hypothesis H. 8 can be announced as follows "Family shareholding has a positive impact on the level of ownership of liquid assets". 
Thus, all the hypotheses put forward can be synthesized as follows:

\section{Table 1}

Variable definition summary

\begin{tabular}{ll}
\hline Variables & Measure \\
\hline Cash Holding (Cash) & Cash and Cash equivalent/Net total assets \\
Debt Ratio (Debt) & Total of long and short-term debt/Total assets \\
Company size (Size) & Natural Logarithm of total assets \\
Working capital requirement (WCR) & Current assets-cash-current liabilities/Total assets \\
Cash-flow (CF) & Earnings before interest + depreciation /Total assets \\
Dividend (DIVID) & Total distributed dividends/Total assets \\
Growth opportunities (Q DE TOBIN) & (Equity+ Liabilities) Market Value/ (Equity + Liabilities) Book Value \\
Ownership Concentration (CONCENT) & Percentage of capital held by the 3 main shareholders \\
Family Shareholding (FAM OWN) & Dichotomous value taking 1 when more than 20\% of the capital is held by a family \\
\hline
\end{tabular}

Table 1 provides the measurement for the explained variable and explanatory variables.

\section{Methodology}

We conducted an empirical econometric study using a positivist approach based on a hypothetico-deductive method according to the methodology advocated by Gill and Johnson (2010). We used data obtained from the financial reports of 42 firms publicly traded on the Casablanca Stock Exchange during the period 2007-2019. These companies were selected for two main reasons. Firstly, listed companies have access to both financing markets, namely the banking and capital markets, which gives them the capacity to have a comprehensive financing policy and strategy. The second reason lies in the characteristics of accounting and financial data of listed Moroccan firms, which can be considered accessible, exhaustive, and reliable, unlike unlisted companies.

We use panel regression analysis in our study for the advantages it confers compared to time series data, notably a larger sample size, less collinearity, consideration of section heterogeneity, and better efficiency. We perform all the necessary tests to determine the exact nature of this dataset and decide whether it is a homogeneous model with fixed individual effect, or a random effect. Our dependent variable, the level of cash, will be defined by the ratio of cash as well as by the level of cash equivalents on net assets. As for the choice of sampling, the target population includes companies listed on the Moroccan market between 2007 and 2019, the data of which are available on the Casablanca Stock Exchange website. However, in this paper, companies in the financial sector are not included given the specificity of their liquidity needs. Firms for which data are missing or are not listed continuously throughout the complete duration of this study are also eliminated. Analysis of the data for all the companies in the sample reveals the presence of outliers. The existence of these outliers may alter the regression results by masking existing relationships or by artificially revealing them. These points are removed.

\section{Table 2}

Study sample

\begin{tabular}{lll}
\hline & Companies & Observations \\
\hline Starting sample & 75 & 900 \\
- Financial companies & 11 & 132 \\
- Insurance & 5 & 60 \\
-Stock market information missing & 17 & 204 \\
Companies studied & 42 & 501 \\
\hline
\end{tabular}

Table 2 summarizes the characteristics of the companies in the sample between 2007 and 2019.

\section{Results and Discussion}

Using panel data is generally accompanied with issues including multicollinearity and heteroscedasticity, therefore, in the following we will present the diagnostic tests performed to verify these issues.

\subsection{Selection of the Optimal Estimation Model}

The first test performed is the Breusch and Pagan test identify the existence of individual effects. It reveals if the panel model is homogeneous or if there are specific effects for each company. The test hypotheses are presented below:

$\mathrm{H}_{0}$ : The homogeneous model is supposed to be more suitable compared to the fixed effects model.

$\mathrm{H}_{1}$ : The fixed effects model seems more suitable compared to the homogeneous model.

Test results in Table 3 show a p-value $<0.05$, which leads us to reject $\mathrm{H} 0$ in favor of $\mathrm{H} 1$. The fixed-effect model is more efficient compared to a homogeneous model. Once the presence of individual effects is established, it is necessary to determine whether 
they should be treated as fixed or random effects by applying the Hausman test for specifying individual effects. The test hypotheses are presented below:

$\mathrm{H}_{0}$ : The random effects model is assumed to be more suitable compared to the fixed effects model

$\mathrm{H}_{1}$ : The fixed effects model seems to be more suitable compared to the random effects model.

Table 3 summarizes the test results and shows that they are not significant. We have a value of $p>0.05$ and therefore we accept the null hypothesis which consists in retaining the random effects model as the most suitable of the three models. However, the homogeneous and fixed-effects models will also be displayed to be used for comparison purposes only.

Table 3

Result of model specification tests

\begin{tabular}{llll}
\hline Test & Chi.Sq.Statistic & Chi-sq-d.f & Prob \\
\hline F-Test & 8.48 & 41,452 & 0 \\
Hausman test & 3.72 & 7 & 0.8113 \\
\hline
\end{tabular}

Table 3 above summarizes the results of the Breush \& Bagan and Hausman tests

\subsection{Descriptive statistics}

The data for our variables were gathered from the reports and financial statements published by the firms. In what follows, we will present descriptive statistics for the sample. On average, the companies in our dataset hold $10.1 \%$ of their net assets in the form of liquidity, although the median cash holding is $4.4 \%$, which shows that some companies hold relatively large amounts of cash relative to the median value; on average, their cash flow represents $17 \%$ of their net assets (the median is $13 \%$ ). Their average size is 8.99 or the equivalent of approximately 990 million Dirhams; the average Tobin Q is 3.09 (the median is 2.35 ). They have an average and median debt ratio of about $36 \%$. On average, they pay out about $6 \%$ of their assets in the form of dividends (median is 4\%), and their working capital requirements represent about $28 \%$ of their net assets (the median is $32 \%$ ). The three main shareholders of the companies in the total sample hold together an average of $67 \%$ of the capital; we also note that $60 \%$ of the companies in our sample are family-owned.

\section{Table 4}

Summary of statistics

\begin{tabular}{|c|c|c|c|c|c|}
\hline Variable & Mean & Median & $\mathrm{SD}$ & Minimum & Maximum \\
\hline Cash & $10.10 \%$ & $4.40 \%$ & $14.30 \%$ & $0.00 \%$ & $83.60 \%$ \\
\hline Debt & $36 \%$ & $36 \%$ & $18 \%$ & $0 \%$ & $98 \%$ \\
\hline Size & 8.99 & 8.97 & 0.63 & 7.5 & 10.63 \\
\hline WCR & $28 \%$ & $32 \%$ & $23 \%$ & $-50 \%$ & $81 \%$ \\
\hline $\mathrm{CF}$ & $17 \%$ & $13 \%$ & $16 \%$ & $-8 \%$ & $144 \%$ \\
\hline DIVID & $6 \%$ & $4 \%$ & $7 \%$ & $0 \%$ & $76 \%$ \\
\hline Tobin'q & 3.09 & 2.35 & 2.56 & -3.48 & 20.07 \\
\hline CONCENT & $67 \%$ & $72 \%$ & $19 \%$ & $9 \%$ & $99 \%$ \\
\hline FAM OWN & $60 \%$ & 0 & 0 & 0 & 1 \\
\hline
\end{tabular}

Table 4 summarizes the characteristics of companies in our sample over the period 2007-2019

The chart 1 below presents the development of the average cash position in our sample between 2007 and 2018 . The average total cash ratio decreases significantly between 2007 and 2010: it goes from 15\% to around 8\% of net assets, then increases in 2013 to reach $10 \%$ of net assets, before decreasing again in 2014 and 2015 to $9 \%$ and stabilizing at around $10 \%$ of net assets between 2016 and 2018. The distribution of liquid assets from one year to the next is fairly homogeneous over the period 20082018 , with the average varying between $8 \%$ in 2008 and $11 \%$ in 2015 , with only 2007 showing a much higher average of $15 \%$.

Table 5 shows the correlation coefficients between the variables in our study. This matrix shows that all the explanatory variables are correlated with the explained variable with a risk of error below 1\% with the exception of the "Shareholding concentration" variable which has a negative but insignificant correlation coefficient. The strongest positive correlation coefficient shows a correlation between cash and cash flow of 0.559 , while the largest negative correlation coefficient concerns financial distress and the holding of liquidity to the value of -0.407 . As for the other significant coefficients, it varies between -0.250 and 0.235 . The correlation coefficients between the explained variable "Cash position" and the explanatory variables: cash flow, dividend and family shareholding are significant and positive, whereas the variables size, indebtedness, financial distress, Tobin's Q, and 
B. Mouline and H. Sadok /Accounting 7 (2021)

working capital requirement are all negative and significant. Furthermore, no correlation coefficient reaches the threshold of 0.6 . We can then conclude that our study is not affected by the risk of multicollinearity.

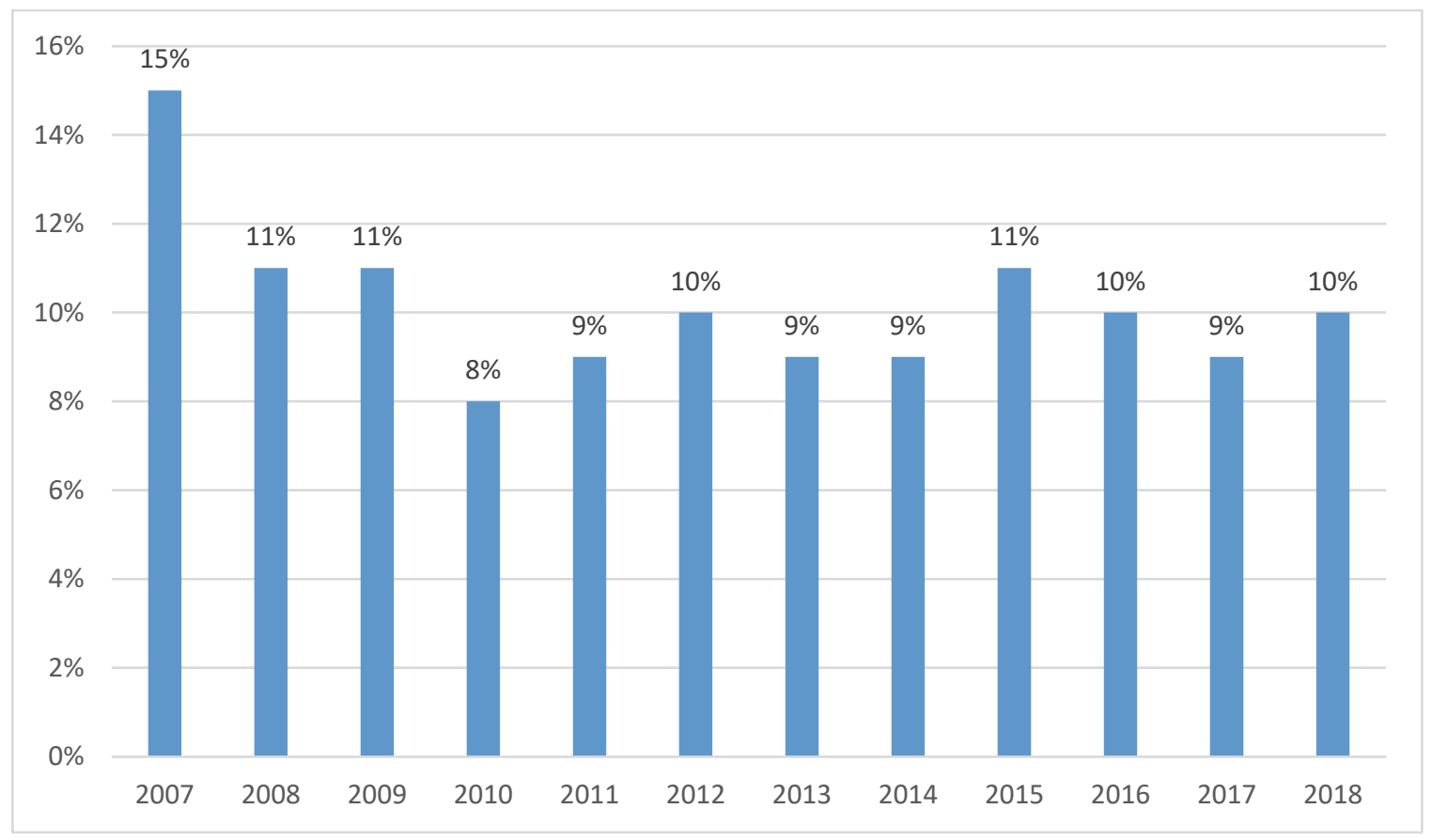

Fig. 1. Evolution of the average cash ratio between 2007 and 2018

\section{Table 5}

Correlation matrix

\begin{tabular}{|c|c|c|c|c|c|c|c|c|c|}
\hline Variable & Cash & Debt & $\mathrm{CF}$ & Size & WCR & DIVID & TOBIN'Q & CONCENt & FAMOWn \\
\hline \multirow{2}{*}{ Cash } & 1 & -0.249 & 0.559 & -0.19 & -0.166 & 0.235 & -0.139 & -0.054 & 0.125 \\
\hline & & ** & $* *$ & $* *$ & $* *$ & $* *$ & $* *$ & & $* *$ \\
\hline \multirow{2}{*}{ Debt } & -0.249 & 1 & -0.216 & 0.312 & -0.307 & -0.294 & 0.254 & 0.111 & 0.249 \\
\hline & $* *$ & & $* *$ & $* *$ & $* *$ & ** & $* *$ & $*$ & $* *$ \\
\hline \multirow[b]{2}{*}{$\mathrm{CF}$} & 0.559 & -0.216 & 1 & -0.019 & -0.159 & 0.517 & 0.125 & -0.047 & 0.098 \\
\hline & ** & $* *$ & & & $* *$ & $* *$ & $* *$ & & * \\
\hline \multirow{2}{*}{ Size } & -0.19 & 0.312 & -0.019 & 1 & -0.287 & 0.174 & 0.315 & 0.144 & -0.198 \\
\hline & $* *$ & $* *$ & & & $* *$ & $* *$ & $* *$ & $* *$ & $* *$ \\
\hline \multirow{2}{*}{ WCR } & -0.166 & -0.307 & -0.159 & -0.287 & 1 & -0.14 & -0.268 & -0.322 & 0.091 \\
\hline & $* *$ & ** & $* *$ & $* *$ & & $* *$ & $* *$ & $* *$ & $*$ \\
\hline \multirow{2}{*}{ DIVID } & 0.235 & -0.294 & 0.517 & 0.174 & -0.14 & 1 & 0.209 & 0.051 & -0.024 \\
\hline & $* *$ & $* *$ & $* *$ & $* *$ & $* *$ & & $* *$ & & \\
\hline \multirow{2}{*}{ TOBIN'Q } & -0.139 & 0.254 & 0.125 & 0.315 & -0.268 & 0.209 & 1 & 0.216 & 0.007 \\
\hline & $* *$ & $* *$ & $* *$ & ** & $* *$ & $* *$ & & $* *$ & \\
\hline \multirow{2}{*}{ CONCENt } & -0.054 & 0.111 & -0.047 & 0.144 & -0.322 & 0.051 & 0.216 & 1 & 0.084 \\
\hline & & $*$ & & $* *$ & $* *$ & & $* *$ & & \\
\hline \multirow{2}{*}{ FAM Own } & 0.125 & 0.249 & 0.098 & -0.198 & 0.091 & -0.024 & 0.007 & 0.084 & 1 \\
\hline & $* *$ & $* *$ & $*$ & $* *$ & $*$ & & & & \\
\hline
\end{tabular}

** The correlation is significant at the 0.01 level (two-tailed)

* The correlation is significant at the 0.05 level

Table 5 presents the Pearson correlation coefficients between all the explanatory and explanatory variables. We note that no correlation problems exist between the variables that could bias our results. 


\subsection{Regression results and interpretation}

This section presents the results of the following three regression models that we estimated to analyse the determinants of the level of cash for our total sample by estimating the following equation:

$$
\text { Cash }_{i, t}=\alpha+\beta_{1} \text { Size }_{i, t}+\beta_{2} \text { Cash flow }_{i, t}+\beta_{3} \text { Debt }_{i, t}+\beta_{4} \text { WCR }_{i, t}+\beta_{5} \text { Dividend }_{i, t}+\beta_{6} \text { Q Tobin }_{i, t}+\beta_{7} \text { CONCENT }_{i, t}+\beta_{9} \text { Fam own }+\varepsilon_{i, t}
$$

Table 6

Regression results

\begin{tabular}{|c|c|c|c|}
\hline VARIABLE & OLS & FIXED EFFECTS & RANDOM EFFECTS \\
\hline Debt & $\begin{array}{c}-0,150 \\
* * *\end{array}$ & $\begin{array}{c}-0.154 \\
* * *\end{array}$ & $\begin{array}{c}-0.156 \\
* * *\end{array}$ \\
\hline $\mathrm{CF}$ & $\begin{array}{c}0,463 \\
* * *\end{array}$ & $\begin{array}{c}0.487 \\
* * *\end{array}$ & $\begin{array}{l}0.48 \\
* * *\end{array}$ \\
\hline Size & $\begin{array}{c}-0,022 \\
* *\end{array}$ & 0.027 & -0.008 \\
\hline WCR & $\begin{array}{c}-0,153 \\
* * *\end{array}$ & $\begin{array}{c}-0.149 \\
* * *\end{array}$ & $\begin{array}{c}-0.145 \\
* * *\end{array}$ \\
\hline TOBIN'Q & $\begin{array}{c}-0.009 \\
* * *\end{array}$ & $\begin{array}{c}-0.006 \\
* *\end{array}$ & $\begin{array}{c}-0.006 \\
* * *\end{array}$ \\
\hline DIVID & -0.123 & -0.118 & $\begin{array}{c}-0.135 \\
*\end{array}$ \\
\hline CONCENT & -0.0413 & -0.099 & -0.071 \\
\hline FAM OWN & $\begin{array}{c}0.0362 \\
* * *\end{array}$ & 0 & 0.041 \\
\hline Constant & $\begin{array}{c}0.362 \\
* * *\end{array}$ & -0.0421 & 0.243 \\
\hline Observation & 501 & 501 & 501 \\
\hline R2 & 0.424 & 0.337 & 0.415 \\
\hline F-Test & & $\begin{array}{c}8.48(0.00) \\
* * *\end{array}$ & \\
\hline Hausman Test & & & $3.72(0.81)$ \\
\hline
\end{tabular}

***The correlation is significant at the 0.01 level.

**The correlation is significant at the 0.05 level.

* The correlation is significant at the 0.1 level.

Table 6 presents the estimation results using 3 regression methods: random effects, fixed effects and OLS. The explanatory variables in all regression models are: Size, Debt, Cash flow, Working capital requirement, Dividend, Family shareholding, Shareholder concentration. Our estimation models show that the coefficient debt is significantly negative at the $1 \%$ threshold using all three estimation methods. This result confirms the hypothesis H.1 justified by the pecking order theory which explains that companies favor self-financing over debt financing, and only resort to debt financing when they cannot raise the adequate internal funds. As a result, liquid assets and indebtedness follow opposite trends. Another explanatory variable, working capital requirement, is also significantly negative, at the $1 \%$ threshold using all three estimation methods, thus confirming H.3 explained by the arbitrage theory. The rapid convertibility of receivables and stock into cash gives firms with a high working capital requirement the possibility of holding less liquidity. The coefficient on the size variable is also significantly negative, but only according to the OLS model at the 5\% threshold, thus confirming hypothesis $\mathrm{H} 2$ explained by the arbitrage theory, which states that external financing is more accessible to larger companies and therefore allows them to succeed in reducing external financing costs as a result of their bargaining power with banks and economies of scale. The positive and significant coefficient of cash flow at the $1 \%$ threshold according to our three estimation methods validates our H4 hypothesis based on the pecking order theory. In fact, companies with a high level of cash flow will take advantage of the remaining cash flow beyond the amount needed to finance other profitable projects, debt repayment, and dividend distribution in order to expand the company's treasury. The dividend variable has a negative effect on the level of cash holdings. This effect is only significant in our random-effect model, thus confirming hypothesis H.5, justified by the trade-off theory which states that dividends could be considered as an alternative source of cash. Growth opportunities have a negative and significant effect on cash assets at the $1 \%$ threshold according to our three models. This negative sign is justified by agency theory, which explains that the risk of over-investment is greater when companies have available liquidity funds and few investment opportunities, given that directors are more inclined to collect the most cash in order to expand their discretionary power and increase their rooting within the company. This result confirms hypothesis H.6. Similar to previous empirical results, family-controlled companies in our sample retain significantly higher liquidity, which confirms hypothesis H.8 justified by agency theory, insofar as family shareholders apply more in the management of the firm, which increases agency conflicts. The only variable that shows a result contrary to our prediction is the shareholder concentration variable. However, this result is not significant in any of our regression models. 
This article examines the reasons for retaining liquidity of non-financial companies listed on the Casablanca Stock Exchange during the period 2007-2019 in the context of three explanatory theories of liquidity holding: trade-off theory, pecking order theory, and agency theory. In line with the prediction of the trade-off theory, our results indicate that small companies facing higher transaction costs, and firms without a large working capital requirement, accumulate significantly higher cash reserves. We were also able to show that companies that distribute dividends have a lower level of liquidity. Our results are also consistent with explanations drawn from the pecking order theory. The results indicate that the amount of indebtedness is negatively related to liquidity, since companies only resort to debt when they have exhausted their equity capital. The results also show that cash flow is significantly and positively linked with the level of liquidity. Regarding the two variables of growth opportunities and family shareholding, our results corroborate the predictions of agency theory, and show a significantly negative relationship between growth opportunities and cash, and a significant positive impact of family shareholding on the level of liquidity. However, our study found no proof of a significant effect of shareholding concentration on liquidity. Our results do not give us the opportunity to come out in favor of a single theory explaining the level of cash, given the importance of each of them in explaining the cash holding behavior of Moroccan firms.

The empirical results of this study show, in accordance with the trade-off theory, that large, dividend-distributing, and high working capital requirement companies retain a lower level of cash than other firms. Furthermore, the study shows that family shareholding and growth opportunities are significantly related to liquidity according to predictions based on agency theory. Finally, our study confirms the hypotheses based on hierarchical financing theory and highlighted the existence of a positive and significant relationship between cash flow and liquidity, and a negative relationship between debt and cash levels.

\section{References}

Afza, T., \& Adnan Sh, M. (2007). Determinants of Corporate Cash Holdings: A Case Study of Pakistan. Singapore Economic review and University of Manchester, 164-165.

Al-Najjar, B., \& Belghitar, Y. (2011). Corporate cash holdings and dividend payments: evidence from simultaneous analysis. Managerial and Decision Economics, 32(4), 231-241. https://doi.org/10.1002/mde.1529

Anderson, R. W., \& Hamadi, M. (2009). Large powerful shareholders and cash holding. Luxembourg School of Finance Research Working Paper Series 09.

Arora, R. K. (2019). Corporate Cash Holdings: An Empirical Investigation of Indian Companies. Global Business Review, 20(4), 1088-1106. https://doi.org/10.1177/0972150919844911

Baklouti, I., \& Bouri, A. (2015). Les déterminants de la détention de trésorerie. La Revue des Sciences de Gestion, 3, 57-65. https://doi.org/10.3917/rsg.273.0057

Bates, T. W., Kahle, K. M., \& Stulz, R. M. (2009). Why Do U.S. Firms Hold So Much More Cash than They Used To? The Journal of Finance, 64(5), 1985-2021. doi:10.1111/j.1540-6261.2009. 01492.x

Baumol, W. J. (1952). The Transactions Demand for Cash: An Inventory Theoretic Approach. The Quarterly Journal of Economics, 66(4), 545-556. https://doi.org/10.2307/1882104

Beckhart, B. H., \& Keynes, J. M. (1936). The General Theory of Employment, Interest and Money. Political Science Quarterly, 51(4), 600. https://doi.org/10.2307/2143949

Bigelli, M., \& Sánchez-Vidal, J. (2012). Cash holdings in private firms. Journal of Banking \& Finance, 36(1), 26-35. https://doi.org/10.1016/j.jbankfin.2011.06.004

Chrisman, J. J., Chua, J. H., Pearson, A. W., \& Barnett, T. (2010). Family Involvement, Family Influence, and Family-Centered Non-Economic Goals in Small Firms. Entrepreneurship Theory and Practice, 36(2), 267-293. https://doi.org/10.1111/j.1540-6520.2010.00407.x

Couderc, N. (2006). La détention d'actifs liquides par les entreprises. Revue économique, 57(3), 485-496. https://doi.org/10.3917/reco.573.0485

De Cesari, A. (2012). Expropriation of minority shareholders and payout policy. The British Accounting Review, 44(4), 207-220. https://doi.org/10.1016/j.bar.2012.09.002

Diamond, D. W. (1989). Reputation Acquisition in Debt Markets. Journal of Political Economy, 97(4), 828-862. https://doi.org/10.1086/261630

Drobetz, W., \& Grüninger, M. C. (2007). Corporate cash holdings: Evidence from Switzerland. Financial Markets and Portfolio Management, 21(3), 293-324. https://doi.org/10.1007/s11408-007-0052-8

Ferreira, M. A., \& Vilela, A. S. (2004). Why Do Firms Hold Cash? Evidence from EMU Countries. European Financial Management, 10(2), 295-319. https://doi.org/10.1111/j.1354-7798.2004.00251.x

García-Teruel, P. J., \& Martínez-Solano, P. (2008). On the Determinants of SME Cash Holdings: Evidence from Spain. Journal of Business Finance \& Accounting, 35(1-2), 127-149. https://doi.org/10.1111/j.1468-5957.2007.02022.x

Gill, J., \& Johnson, P. (2010). Research Methods for Managers. Sage Publications 4th Edition. London. 
Gomes, A. R., \& Novaes, W. (2001). Sharing of Control as a Corporate Governance Mechanism. SSRN Electronic Journal, 1-29. https://doi.org/10.2139/ssrn.277111

Graham, J. R., \& Leary, M. T. (2018). The Evolution of Corporate Cash. The Review of Financial Studies, 31(11), 4288-4344. https://doi.org/10.1093/rfs/hhy075

Guney, Y., Ozkan, A., \& Ozkan, N. (2003). Additional International Evidence on Corporate Cash Holdings. SSRN Electronic Journal. doi:10.2139/ssrn.406721

Guney, Y., Ozkan, A., \& Ozkan, N. (2007). International evidence on the non-linear impact of leverage on corporate cash holdings. Journal of Multinational Financial Management, 17(1), 45-60. https://doi.org/10.1016/j.mulfin.2006.03.003

Harford, J., Mansi, S., \& Maxwell, W. F. (2006). Corporate Governance and Firm Cash Holdings. SSRN Electronic Journal, 535-555. https://doi.org/10.2139/ssrn.595150

Jensen, M. C. (1999). Agency Cost of Free Cash Flow, Corporate Finance, and Takeovers. SSRN Electronic Journal, $323-329$. https://doi.org/10.2139/ssrn.99580

Jensen, M. C., \& Meckling, W. H. (1976). Theory of the firm: Managerial behavior, agency costs and ownership structure. Journal of Financial Economics, 3(4), 305-360. https://doi.org/10.1016/0304-405x(76)90026-x

Kalcheva, I., \& Lins, K. V. (2006). International Evidence on Cash Holdings and Expected Managerial Agency Problems. SSRN Electronic Journal, 1087-1112. https://doi.org/10.2139/ssrn.477241

Kim, C.-S., Mauer, D. C., \& Sherman, A. E. (1998). The Determinants of Corporate Liquidity: Theory and Evidence. The Journal of Financial and Quantitative Analysis, 33(3), 335-358. https://doi.org/10.2307/2331099

Kuan, T.-H., Li, C.-S., \& Chu, S.-H. (2011). Cash holdings and corporate governance in family-controlled firms. Journal of Business Research, 64(7), 757-764. https://doi.org/10.1016/j.jbusres.2010.07.004

Laeven, L., \& Levine, R. (2007). Complex Ownership Structures and Corporate Valuations. Review of Financial Studies, 21(2), 579-604. https://doi.org/10.1093/rfs/hhm068

La Cava, G., \& Windsor, C. (2016). Why do companies hold cash?. No. rdp2016-03, Reserve Bank of Australia, Sydney.

Levasseur, M. (1979). Gestion de trésorerie , Economica

Maheshwari, Y., \& Rao, K. V. (2017). Determinants of Corporate Cash Holdings. Global Business Review, 18(2), $416-427$. doi:10.1177/0972150916668610

Miller, M. H., \& Orr, D. (1966). A Model of the Demand for Money by Firms. The Quarterly Journal of Economics, 80(3), 413-435. https://doi.org/10.2307/1880728

Mulligan, C. B. (1997). Scale Economies, the Value of Time, and the Demand for Money : Longitudinal Evidence from Firms. Journal of Political Economy, 105(5), 1061-1079. https://doi.org/10.1086/262105

Myers, S. C., \& Majluf, N. S. (1984). Corporate financing and investment decisions when firms have information that investors do not have. Journal of Financial Economics, 13(2), 187-221. https://doi.org/10.1016/0304-405x(84)90023-0

Opler, T., Pinkowitz, L., Stulz, R., \& Williamson, R. (1999). The determinants and implications of corporate cash holdings. Journal of Financial Economics, 52(1), 3-46.

Ozkan, A., \& Ozkan, N. (2004). Corporate cash holdings: An empirical investigation of UK companies. Journal of Banking \& Finance, 28(9), 2103-2134. https://doi.org/10.1016/j.jbankfin.2003.08.003

Shleifer, A., \& Vishny, R. W. (1986). Large Shareholders and Corporate Control. Journal of Political Economy, 94(3, Part 1), 461-488. doi:10.1086/261385

Smith, C. W., \& Warner, J. B. (1979). On financial contracting. Journal of Financial Economics, 7(2), 117-161. doi:10.1016/0304-405x(79)90011-4

Titman, S., \& Wessels, R. (1988). The Determinants of Capital Structure Choice. The Journal of Finance, 43(1), 1-19. doi:10.1111/j.1540-6261.1988.tb02585.x

Yogesh, M., \& Vigneswara, R. (2017). Determinants of Corporate Cash Holdings. Global Business Review, 18, 416-427

Younas, Z. I., Klein, C., \& Zwergel, B. (2017). The effects of ownership concentration on sustainability: A case of listed firms from USA, UK and German. Corporate Ownership and Control, 14(3), 113-121. https://doi.org/10.22495/cocv14i3art11

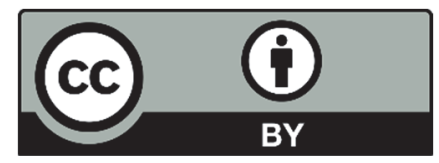

(C) 2021 by the authors; licensee Growing Science, Canada. This is an open access article distributed under the terms and conditions of the Creative Commons Attribution (CC-BY) license (http://creativecommons.org/licenses/by/4.0/). 